\title{
Influence of Servant Leadership to Motivation, Organization Culture, Organizational Citizenship Behavior (OCB), and Employee's Performance in Outstanding Cooperatives East Java Province, Indonesia
}

\author{
Wiwiek Harwiki \\ Doctoral Student of Business Administration, Faculty of Administrative Science, Brawijaya \\ University, Malang, Indonesia
}

\begin{abstract}
Servant leadership style implementation on Cooperatives encourages the existence of organizations. Since most organizations -including Cooperatives-need to serve at all levels in order to keep their relationship to their members, employees, and environments. Servant leadership should be of interest for today's cooperative leaders for it enablesand empowers employees to serve others.

25 Cooperatives have been honored as Outstanding Cooperatives in 2012 based on East Java Governor Act (SK GubernurJawaTimurNomor 188/389/KPTS/013/2012) were as an object of this research is located inEast Java. The data were obtained from 249 Employees, and 30 Managers of Outstanding Cooperatives. The data were analyzed using the Structural Equation Modeling with Partial Least Square Program. Empirical research on servant leadership has been scarce (Subramaniam, 2011), so this study will contribute to the body of knowledge with attempt to investigate the influences of servant leadership to motivation, organization culture, $O C B$, and employees' performance; and the influences of motivation to $O C B$, and employees' performance; and the influences of organization culture to $O C B$, and to employees' performance; and the influence of $O C B$ to employees' performance. The research showed the following findings: (1)servant leadership influences to motivation, organization culture, and employees' performance, but not to $O C B$; (2) motivation influences to $O C B$ and employees' performance; (3) organization culture influences to OCB and employees' performance, and (4) OCB influences to employees' performance of Outstanding Cooperatives in East Java. Suggestion that can be presented is that managers of Outstanding Cooperatives should be more empower themselves to help fellow workers carry out their tasks voluntarily, and implementing the real positive attitude, fostering sportsmanship, altruism, conscientiousness, courtesy, and civic virtue of the employees.

Keywords: Servant Leadership, Motivation, Organization Culture, OrganizationalCitizenship Behavior $(O C B)$, and Employees' Performance.
\end{abstract}

\section{Background}

East Java as one of the biggest Province in Indonesia has more than 4,2 millions Small Medium Enterprises, number of Cooperatives was 29.145 units and absorbed man power as many as 75.430 people, with total business volume of about 26,29 trillions rupiahs in 2011 (Central Bureau of Statistic, 2012). Many reasons of conducting research on Outstanding Cooperatives as follows: (1) $0.08 \%$ of 29.145 units only (25 units) as Outstanding Cooperatives shows not only so rigid and competitive, but also as a big opportunity to be an Outstanding Cooperatives in East Java, (2) The result of Outstanding Cooperatives research beneficial as a trigger for ordinary other Cooperatives hopefully, and (3) The previous research of servant leadership has been conducted on voluntary organization and big company (Covey, 1995), not on Cooperatives, especially Outstanding Cooperatives.

Servant leadership in Cooperatives relate to serve first, rather than to lead first, always striving to meet the highest priority needs of others. Servant leadership respects the capabilities of their followers and enable them to exercise their abilities, share powers, and do their best. The servant-leader is prepared to share power through empowerment, thereby involving followers in planning and decision making.

Along with the servant leadership style of Outstanding Cooperatives which show concern for their employees, the overriding focus of the servant leader is upon service to the employees, as Russell (2001) stated that the servant leader are people oriented and focused on the needs of those around them. The existence of Small Medium and Cooperatives in East Java economic growths is important, especially in supporting of 53.04\% for Total PDRB (Product Domestic Regional Brutto) on 2011 (Central Bureau of Statistic, 2012)- , means that leadershipare needed from the leaders who motivate their subordinates achieving a certain level that exerting a given level of effort will lead to a higher performance. 
Furthermore, the servant leadership can be operationalized and is well suitable for application in the information service arena like organizations not-for-profit, volunteer or educational institutions (Smith, 2004), as well for Outstanding Cooperatives hopefully. This study examine (1) the influence of servant leadership to motivation, organization culture, $\mathrm{OCB}$, and employees' performance, (2) the influence of motivation to OCB and employees' performance, (3) the influence of organization cultureto OCB and employees' performance, and (4) the influence of OCB to employees' performance.

\section{Theoretical Review}

Servant leadership is a term referred to by a surprising number of leadership writers and researchers. Senge (as cited in Spears, 1995) emphasized the importance of the concept by stating that he believes the essay by Robert Greenleaf titled The Servant as Leader, is the most useful statement on leadership in the last 20 years. Covey (1995) summarized his view of servant leadership by stating that "you don't just serve, you do it in a way that makes them independent of you, and capable and desirous of serving other people". That was close to the first part of Greenleaf's (1970) best test of servant leadership that asks "When served, do they grow as persons?", while Bass and Avolio(1999) point out thatleaders who adopt transformational leadership style successfully motivate theiremployees, and Storseth (2004) suggested that a leadership style involving a "people-orientation" wasidentified as a key predictor for work motivation.

Hofstede (1980) refer culture as software of the mind that support in our daily interaction. Several researchers proved the linkage between leadership and organizational culture (Bass, 1985; Doherry, 1991; Trice and Beyer, 1991). Bass (1985) conducted study on leadership style and its impact on culture, and found that transactional leaders operate in a boundary of existing culture, while transformation leaders operate to align the culture of the organization with vision of the organization. Jogulu (2010) found that leadership style changes as the culture of the organization changes. Sabiret al. (2011) gave the model provides link between leadership style, organization culture, and organization commitment, and recommended that future research can be conducted with new variable i.e. servant leadership style in the model by replacing the transactional leadership.

Work behavior or known as OCB in the organization that is committed to improving service quality is also very important to be developed or nurtured. Organ (1998), defined OCB as individual behavior that is discretionary, not directly or explicitly recognized by the formal reward system, and the aggregate promotes the effective functioning of the organization. Zabihi and Hashemzehi (2012) proved empirically that style of leaderships(transactional or transformational) have significant impact and partially influence the OCB.

Individual performance has become a topical issue in today's business environment, so much that organizations go to great lengths to appraise and manage it (Armstrong and Baron, 1998). The role of leadership support the competition process is further substantiated in Hall's Competence Process(1998) which depicts performance as a dependent of collective competence.Recent research using motivation to measure an individual's disposition has renewed interest in examining Organ's (1998) model proposing that an individual's motives may relate to his or her OCB (Penneret al., 1997). Tang and Ibrahim (1998) explored the impact of personality and motivation on OCB. Barbutoet al. (2001) argued that though the motivational theories work as antecedents for OCB, while Jahangir et al. (2004) cautioned that an individual's sources of motivation could have an impact on his or her level of OCB.

Motivation is the desire within a person that encourages him/her to perform an action, where one often takes an action to achieve a particular goal ( Mathis and Jackson, 2002), Lawler (1994) and Buchanan and Huczynski (1997) maintain that although a variety of idiosyncratic factors (such as the individual's abilities, skills, personal traits and understanding of his role), as well as a number of situational and environmental parameters (for example, the size, structure and culture of the organization, the management, control, and leadership systems and styles in place) exert some effects on the way individuals perform in the organizational setting, motivation still seems to be the single most important determinant of individual job performance. Sari and Ja'far (2010) found a positive relationship between motivation and manager's performance.

Existing studies consistently have shown that organizational culture is associated with OCB (Wayne $e t$ al., 1997; Werner, 2000). Further, Werner (2000) postulates that the organizational culture influences on the extent to which employees are engaged in contextual performance which is defined as "individual efforts that are not directly related to their main task functions but are important because they shape the organizational, social, and psychological context that serves as the critical catalyst for task activities and processes". The finding of Jo and Joo (2011) showed that organizational learning culture positively related to OCB.

It is the fact that organizational culture can offer a shared system of meanings,according to Campbell and Stonehouse(1999), culture can also have influence on: employee motivation, employee morale and "good will" ; productivity and efficiency; the quality of work; innovation and creativity, the attitude and the performance of employees in the workplace. The results of studies by Di Tomasso (1992), Nystrom (1993), Fey \& Denison (2000), all suggest that organization culture is positively and significantly associated with employees' performance. With reference to Indian organizations, a review literature suggest that dimensions of 
OCB such as altruism, conscientiousness, and civic virtue match with society as India, and would thus have a positive impact on individual performance (Hofstede, 2001).

\section{Material And Methods}

The research was conducted in the East Java Province as a whole currently has 17 districts as the area within 25 units Outstanding Cooperatives. Population in this study includes all employees and managers in Outstanding Cooperatives in East Java, consisting of 659 employees, 40 managers, 4 unit businesses. Sampling technique used was the area sampling or cluster sampling that takes samples based on area/region (Bungin, 2011). Population divided into certain huge unit is called cluster, then counting it in each area/cluster based on sample measured by Slovin formula and proportionally at $5 \%$.

Structural Equal Modeling (SEM) is used as a technique of analysisin this research, because of the complexity model and the limitation of multi dimension analysis tools in quantitative research such as multiple regression, factor analysis, and descriminant analysis. SEM is an analytical technique used to test a set of complicated relationship among variables simultancy. These complex relationships consist of more than one dependent variables with many independent variables. Each constructs is created by indicator variables (Ferdinand, 2006).

\section{Conceptual Framework And Hypothesis}

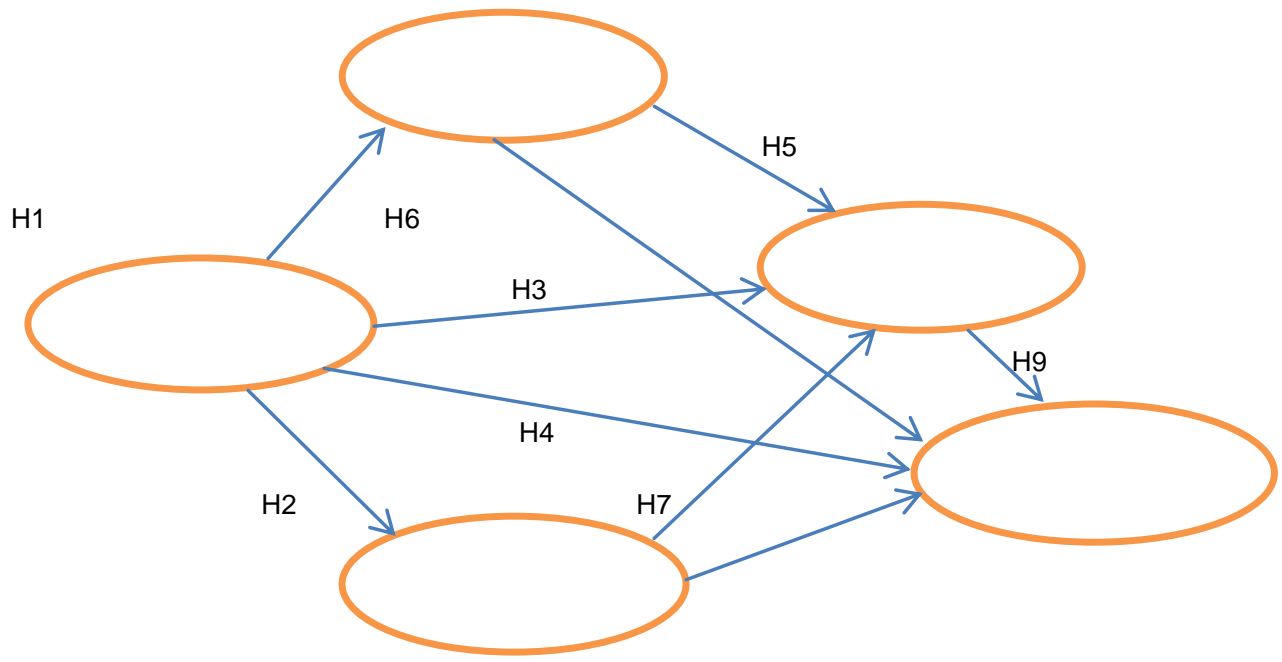

Fig. 1 Conceptual Framework

Based on Conceptual Framework, hypothesis of this research are:

The first hypothesis states that Servant Leadership influences significantly to Motivation in Outstanding Cooperatives in East Java.

The second hypothesis states that Servant Leadership influences significantly to Organization Culture in Outstanding Cooperatives in East Java.

The third hypothesis says Servant Leadership influences significantly OCB in Outstanding Cooperatives in East Java.

The fourth hypothesis says that Servant Leadership influences significantly to Employees' Performance in Outstanding Cooperatives in East Java.

The fifth hypothesis says that Motivation influences significantly to OCB in Outstanding Cooperatives in East Java.

The sixth hypothesis says that Motivation influences significantly to Employees' Performance in Outstanding Cooperatives in East Java.

The seventh hypothesis says that Organization Culture influences significantly to OCB

in Outstanding Cooperatives in East Java.

The eighth hypothesis says that Organization Culture influences significantly to Employees' Performance in Outstanding Cooperatives in East Java.

The ninth hypothesis says that OCB influences significantly to Employees' Performance in Outstanding Cooperatives in East Java.

\section{RESULTS}




\subsection{Testing Instrument}

The following tables are presented testing the validity and reliability of research instrument for each variables. Table 1 shows that all correlation values of each indicators and items were above 0.3. Thus the overall indicators and items have valid questions. While the Cronbach Alpha values obtained from the above 0.6 for the whole variables so it can be concluded that the instrument was valid research data.

Table 1. Validity and Reliability Test

\begin{tabular}{|c|c|c|c|c|c|c|c|c|c|c|}
\hline Indikator & \multicolumn{2}{|c|}{$\mathrm{X} 1$} & \multicolumn{2}{|c|}{ Y1 } & \multicolumn{2}{|c|}{ Y2 } & \multicolumn{2}{|c|}{$\mathbf{Y 3}$} & \multicolumn{2}{|c|}{ Y4 } \\
\hline 1 & $\mathrm{X} 1.1 .1$ & 0.007 & Y1.1.1 & 0.011 & Y2.1.1 & 0.002 & Y3.1.1 & 0.006 & Y4.1.1 & 0.001 \\
\hline 2 & $\mathrm{X} 1.1 .2$ & 0.042 & Y1.1.2 & 0.004 & Y2.1.2 & 0.002 & Y3.1.2 & 0.005 & Y4.1.2 & 0.014 \\
\hline 3 & $\mathrm{X} 1.1 .3$ & 0.001 & Y1.1.3 & 0.00 & Y2.2.1 & 0.002 & Y3.2.1 & 0.049 & Y4.1.3 & 0.023 \\
\hline 4 & $\mathrm{X} 1.2 .1$ & 0.001 & Y1.2.1 & 0.003 & Y2.2.2 & 0.007 & Y3.2.2 & 0.003 & Y4.2.1 & 0.000 \\
\hline 5 & $\mathrm{X} 1.2 .2$ & 0.000 & $\mathrm{Y} 1.2 .2$ & 0.006 & Y2.2.3 & 0.001 & Y3.3.1 & 0.000 & Y4.2.2 & 0.002 \\
\hline 6 & $\mathrm{X} 1.2 .3$ & 0.006 & Y1.2.3 & 0.002 & Y2.3.1 & 0.007 & Y3.3.2 & 0.004 & Y4.2.3 & 0.001 \\
\hline 7 & $\mathrm{X} 1.3 .1$ & 0.020 & Y1.3.1 & 0.006 & Y2.3.2 & 0.003 & Y3.4.1 & 0.014 & Y4.3.1 & 0.002 \\
\hline 8 & $\mathrm{X} 1.3 .2$ & 0.013 & $\mathrm{Y} 1.3 .2$ & 0.007 & Y2.4.1 & 0.000 & Y3.4.2 & 0.001 & Y4.3.2 & 0.007 \\
\hline 9 & $\mathrm{X} 1.3 .3$ & 0.046 & $\mathrm{Y} 1.3 .3$ & 0.010 & Y2.4.2 & 0.006 & Y3.5.1 & 0.000 & Y4.3.3 & 0.000 \\
\hline 10 & $\mathrm{X} 1.4 .1$ & 0.000 & Y1.3.4 & 0.006 & & & Y3.5.2 & 0.008 & & \\
\hline 11 & X1.4.2 & 0.017 & & & & & & & & \\
\hline 12 & $\mathrm{X} 1.4 .3$ & 0.001 & & & & & & & & \\
\hline $\begin{array}{c}\text { Alpha } \\
\text { Cronbanch }\end{array}$ & \multicolumn{2}{|c|}{0.731} & \multicolumn{2}{|c|}{0.667} & \multicolumn{2}{|c|}{0.674} & \multicolumn{2}{|c|}{0.681} & \multicolumn{2}{|c|}{0.697} \\
\hline
\end{tabular}

\subsection{Testing Assumption in SEM}

Assumptions in SEM analysis are normality, linearity and no outliers. For normality testing used softwareAMOS 6. The result is a critical ratio value 7.768 with $\mathrm{Z}_{\text {count }}$ for $5 \%$ is 1.96 . Absolute value $\mathrm{CR}$ for multivariate $7.768>1.96$, so normality assumption is not supported. But based on the center limitation theorem: if more samples taken, the statistic distribution will be normal. 249 samples is appropriate to the theorem and the normality data assumption is not critical, thus can be ignored.

Testing the assumption of linearity was conducted by Curve Fit. The test result showed linearity all significant for the $\mathrm{Sig}<0.05$, thus concluded that the assumption of linearity was met.Mahalanobis distance (Md) $\chi^{2}$ at free degree in parameter model 75 is used to test if any outlier. Founded based on statistic table $\chi_{75}^{2}$ $=118.599$. The farthest observation point is the 207-threspondent at Md=44.816. Comparing with $\chi_{75}^{2}=$ 118.599 , founded thatMd point at 207-th $(44.816)<118.599$. So, concluded that all of the observation points are not outliers.

\subsection{SEM Model Goodness of Fit.}

The result ofgoodness of fit overall model testing is attemptto know if the hypothesis model is supported by empirical data, showedon Table 2 as follow.

Table2. Result Testing of Goodness Of Fit Overall Model

\begin{tabular}{|l|c|c|c|}
\hline \multicolumn{1}{|c|}{ Criterion } & Cut-of value & Result of Model & Interpretation \\
\hline Chi Quadrat & Kecil & 317.292 & \multirow{2}{*}{ Worse Model } \\
\hline p-value & $\geq 0.05$ & 0.000 & \\
\hline CMIN/DF & $\leq 2.00$ & 2.219 & Worse Model \\
\hline GFI & $\geq 0.90$ & 0.843 & Worse Model \\
\hline AGFI & $\geq 0.90$ & 0.848 & Worse Model \\
\hline TLI & $\geq 0.95$ & 0.812 & WorseModel \\
\hline CFI & $\geq 0.95$ & 0.886 & Worse Model \\
\hline RMSEA & $\leq 0.08$ & 0.070 & Good Model \\
\hline
\end{tabular}

Arbuckle and Wothke on Solimun (2009) stated that the best criterion can be used as a goodness indicator model if Chi Square/DF value less than 2, and RMSEA fulfill the cut off value, thus concluded that SEM model is appropriate and suitable to be used for this research. 


\subsection{Measurement Model.}

Indicator with the highest loading factor as the strongest measurementfor the dominant variables showed on Table 3 as follow.

Table 3.Outer Loading Value for Each Variable

\begin{tabular}{|c|c|c|c|c|c|c|c|c|c|c|}
\hline Indicator & \multicolumn{2}{|l|}{$\mathrm{X1}$} & \multicolumn{2}{|l|}{ Y1 } & \multicolumn{2}{|l|}{ Y2 } & \multicolumn{2}{|l|}{ Y3 } & \multicolumn{2}{|l|}{ Y4 } \\
\hline 1 & $\mathrm{X} 1.1$ & $0.471 *$ & $\mathrm{Y} 1.1$ & $0.743^{* *}$ & $\mathrm{Y} 2.1$ & $0.706^{* *}$ & Y3.1 & $0.526^{* *}$ & Y4.1 & $0.699 * *$ \\
\hline 2 & $\mathrm{X} 1.2$ & $0.690 *$ & Y1.2 & $0.663 *$ & Y2.2 & $0.488^{*}$ & Y3.2 & $0.626^{*}$ & Y4.2 & $0.521 *$ \\
\hline 3 & $\mathrm{X} 1.3$ & $0.649 *$ & Y1.3 & $0.608 *$ & Y2.3 & $0.518^{*}$ & Y3.3 & $0.501 *$ & Y4.3 & $0.751 *$ \\
\hline 4 & $\mathrm{X} 1.4$ & $0.626^{* *}$ & & & Y2.4 & $0.718^{*}$ & Y3.4 & $0.612 *$ & & \\
\hline 5 & & & & & & & Y3.5 & $0.600 *$ & & \\
\hline
\end{tabular}

Note: $\quad * \quad: \quad$ weight significant $(\mathrm{p}$-value $<0,05)$

** $\quad: \quad$ weight stated fix (fixed)

Based on Table 3 concluded that:

1. Servant leadershipvariable (X1) consist of 4 indicators: character orientation, people orientation, task orientation and process orientation. The highest loading factor value ispeople orientation (X1.2) as the most dominant factor to support servant leadership.

2. Motivation variable ( $\mathrm{Y} 1)$ consist of 3 indicators: valence, expectancy, and instrumentality. The highest loading factor value is valence (Y1.1) as the most dominant factor to support motivation variable.

3. Organization culturevariable (Y2) consist of 4 indicators: uncertainty avoidance,femininity vs. masculinity, collectivism vs. individualism, and power distance. The highest loading factor value is power distance (Y2.4) as the most dominant factor to support organization culture variable.

4. OCBvariable (Y3) consist of 5 indicators: sportsmanship, civic virtue, conscientiousness, altruism, courtesy. The highest loading factor value is civic virtue (Y3.2) as the most dominant factor to support OCB variable.

5.Employees' performance (Y4) consist of 3 indicators: output, work behavior, and individual attitude.The highest loading factor value is individual attitude (Y4.3) as the most dominant factor to support employees' performance.

\subsection{Structural Model.}

Inner model (structural model) testingto test hypothesis in this research.Hypothesis testing usedTstatistics for each paths and the direct influence partially. Table 4 show the hypothesis result testing of direct influences.

Table 4. Direct Influences Result Testing of Structural Model

\begin{tabular}{|c|c|c|c|c|}
\hline \multicolumn{2}{|c|}{ Variables' Relationship } & Coefficient & P-value & Conclusion \\
\hline X1 & Y1 & 0.343 & 0.000 & Significant 5\% \\
\hline X1 & Y2 & 0.396 & 0.000 & Significant 5\% \\
\hline X1 & Y3 & $\mathbf{0 . 1 3 5}$ & $\mathbf{0 . 2 0 9}$ & Non Significant \\
\hline X1 & Y4 & 0.281 & 0.003 & Significant 5\% \\
\hline Y1 & Y3 & 0.185 & 0.057 & Significant 10\% \\
\hline Y1 & Y4 & 0.281 & 0.001 & Significant 5\% \\
\hline Y2 & Y3 & 0.214 & 0.033 & Significant 5\% \\
\hline Y2 & Y4 & 0.239 & 0.007 & Significant 5\% \\
\hline Y3 & Y4 & 0.293 & 0.001 & Significant 5\% \\
\hline
\end{tabular}

The result of structural model graphically showed as follow. 


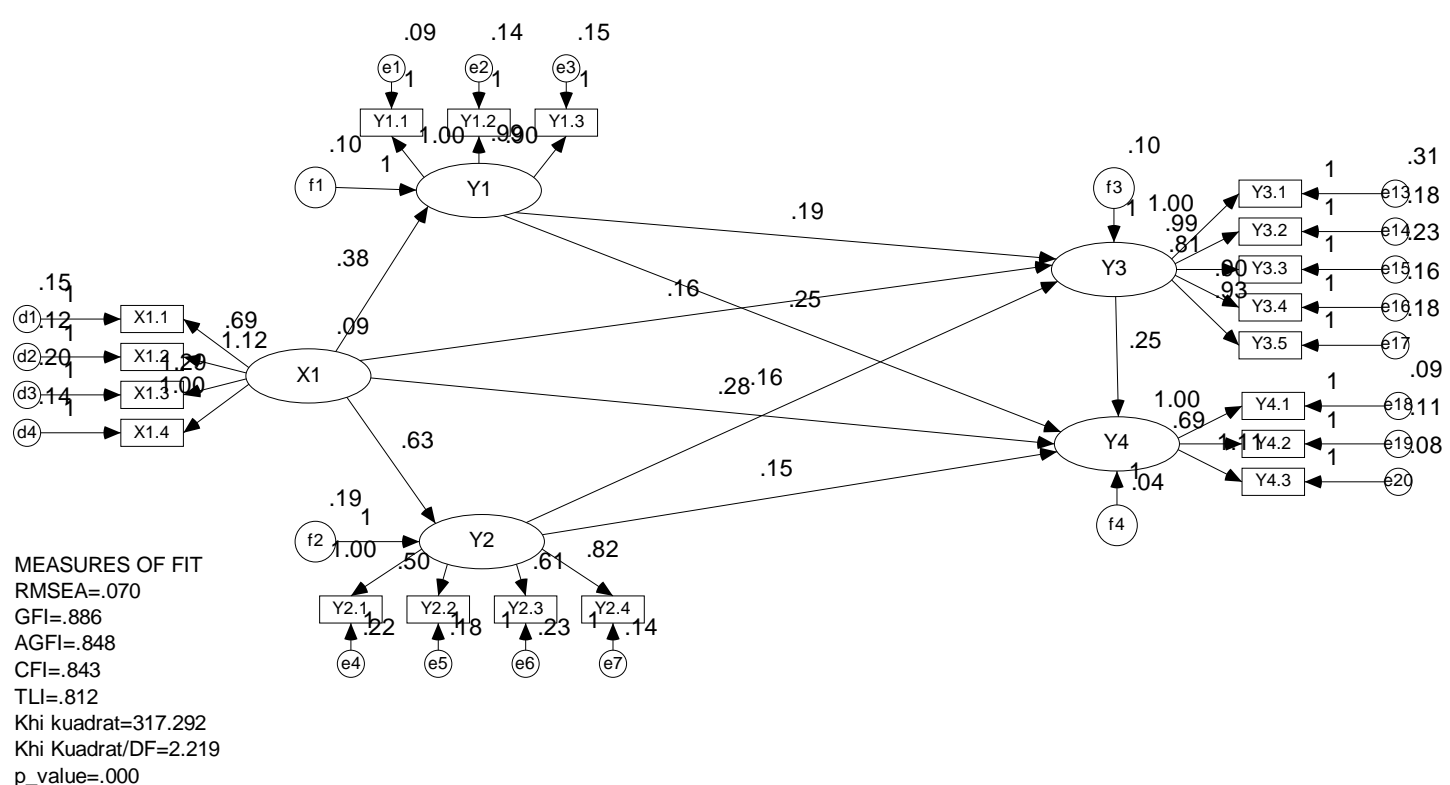

Fig.2. The Result of Inner Model Direct Testing.

Based on Table 4 and Fig. 2, the result of direct influences hypothesis testing as follow:

1. Direct influences testing ofServant Leadership(X1)on Motivation (Y1) founded standardized coefficient value 0.343 with $\mathrm{p}$-value of 0.000 . Because $\mathrm{p}$-value $<5 \%$, there is sufficient evidence to accept the hypothesis that Servant Leadership (X1) influencesMotivation (Y1). Since the coefficient ispositive (0.343), indicating that the higher value of Servant Leadership (X1), will lead to the higher value of Motivation (Y1).

2. Direct influences testing ofServant Leadership (X1)on Organization Culture (Y2) founded standardized coefficient value 0.396 with $\mathrm{p}$-value of 0.000 . Because $\mathrm{p}$-value $<5 \%$, there is sufficient evidence to accept the hypothesis that Servant Leadership (X1) affects Organization Culture (Y2). Since the coefficient is positive (0.396), indicating that the higher value of Servant Leadership (X1), will lead to the higher value of Organization Culture (Y2).

3. Direct influences testing of Servant Leadership (X1)on OCB (Y3) founded standardized coefficient value 0.135 with p-value of 0.209 . Because p-value $>5 \%$, there isinsufficient evidence to accept the hypothesis that ServantLeadership (X1) influencesOCB (Y3). ServantLeadership(X1) has no significaneffectto OCB (Y3), thusthechange of ServantLeadership'svaluewillnotaffecttothechange of OCB'svalue.

4. Direct influences testing ofServant Leadership (X1)on Employees' Performance (Y4) founded standardized coefficient value 0.281 with p-value of 0.003 . Because p-value $<5 \%$, there is sufficient evidence to accept the hypothesis that Servant Leadership (X1) affects Employees' Performance (Y4). Since the coefficient is positive (0.281), indicating that the higher value of Servant Leadership (X1), will lead to the higher value of Employees' Performance (Y4).

5. Direct influences testing ofMotivation (Y1)on OCB (Y3) founded standardized coefficient value 0.185 with $\mathrm{p}$-value of 0.057 . Because $\mathrm{p}$-value $<5 \%$, there is sufficient evidence to accept the hypothesis that Motivation (Y1) affects OCB (Y3). Since the coefficient is positive (0.185),indicating that the higher value ofMotivation (Y1), will lead to the higher value of OCB (Y3).

6. Direct influences testing ofMotivation (Y1)on Employees' Performance (Y4) founded standadized coefficient value 0.281 with $\mathrm{p}$-value of 0.001 . Because $\mathrm{p}$-value $<5 \%$, there is sufficient evidence to accept the hypothesis that Motivation (Y1) affects Employees' Perfromance(Y4). Since the coefficient is positive (0.281), indicating that the higher value ofMotivation (Y1), will lead to the higher value of Employees' Performance (Y4).

7. Direct influences testing ofOrganization Culture (Y2)on OCB (Y3) founded standardized coefficient value 0.214 with p-value of 0.033 . Because $\mathrm{p}$-value $<5 \%$, there is sufficient evidence to accept the hypothesis that Organization Culture (Y2) affects OCB (Y3). Since the coefficient is positive (0.214), indicating that the higher value ofOrganization Culture (Y2), will lead to the higher value of OCB (Y3).

8. Direct influences testing ofOrganization Culture (Y2)on Employees' Performance (Y4) founded standardized coefficient value 0.239 with $\mathrm{p}$-value of 0.007 . Because $\mathrm{p}$-value $<5 \%$, there is sufficient evidenceto accept the hypothesis that Organization Culture (Y2) affects Employees' Performance (Y4). Since the coefficient is positive (0.239), indicating that the higher value ofOrganization Culture (Y2), will lead to the higher value of Employees' Performance (Y4). 
9. Direct influences testing ofOCB (Y3)on Employees' Performance (Y4) founded standardized coefficient value 0.293 with $\mathrm{p}$-value of 0.001 . Because $\mathrm{p}$-value $<5 \%$, there is sufficient evidence to accept the hypothesis that OCB (Y3) affects Employees' Performance (Y4). Since the coefficient is positive (0.293), indicating that the higher value ofOCB (Y3), will lead to the higher value of Employees' Performance (Y4).

This study is in line with Mehta et al. (2003) and Chipunza (2011), both found that leadership styles influence on motivation and proved that there is a significant relationship between different leadership style on employee motivation.Servant leadership concerned with developing human resources, focusing on the leader's relationship with people and his commitment to develop followers, as Greenleaf (1970) stated that all is needed to rebuild community by caring, empowering and developing others.Leaders must employ motivation to influence followers in achieving goals and objectives.

Theoretically, Hofstede (1980) identified that culture as software of the mind can be impacted by leadership style. This study is consistent with several researches by Bass (1985) and Sabiret al. (2011), both found that leadership style impacts on culture, and leadership style changes as the culture of the organization changes.Although servant leaders understand that primary function as a leader is to serve the need of others and help subordinates, but sometimes their behavior disconnected with their beliefs, simply because they are not willing to address the evils of abusive power and egoistic pride (Wong and Page, 2003), in line with this research that no significant were found between Servant Leadershipon OCB, butthisresultdidnotsupportBudiyanto and Oetomo (2011) suggested that leadership is positively and significantly related to OCB.

Hall (1996) statedthatorganizationalleadershipinfluencesemployees' performance directly and indirectly. Hayward (2005) initially revealed a weak mildly significant negative linear relationship between employee performance and leadership. Furthermore, it was found that there was a significant weak, negative linear relationship between employee performance and transactional leadership. So this result supported Hall (1996) and enhanced Hayward (2005).

The result consistent with study of Jahangiret et al. (2004) and Kim (2001) found that motivation and employee age have a positive relationship between OCB and performance of organization.Motivation does exist and that employees are more likely to place a higher value on the intrinsic reward of work that is important and provides a feeling of accomplishment (Houston, 2000). Thus, it is possible to conclude that motivation related with OCB.In general, individual who are highly motivated are much more likely to be high performance, as this study revealed that motivation have a positive relationship with employees' performance, and in line with the study by Koesmono (2005) proved that motivation of managers influence their individual performance.

The culture of organization should be develop to support employees' style of helping others as a good teamwork. This study supportedthe existing studies of Somech\&Drach-Zagavy (2004) and Williams\&Anderson (1991) provide empirical evidence on positive influence organization culture to OCB.

OCB behaviors are vital for productivity: organizations cannot forecast the entire spectrum of subordinate needed for achieving goals through stated job descriptions (Deluga, 1994), but normally such behaviors are not specifically rewarded by organizations who demonstrate such behaviors are often seen having a favorable attitude towards overall business efficacy (Smith et al., 1983). In this connection, Pattnaik and Biswas (2005) and Biswas and Varma (2007) found that OCB had a positive impact on individual performance. The result showed an influence of OCB to employees' performance

\section{Conclusions And Recommendations}

Several conclusions can be obtained as follow: (1) there is the influence of servant leadership to motivation, organization culture, and employees' performance, but servant leadership has not influence to OCB; the higher the servant leadership, it could lead to higher the motivation, organization culture and employees' performance, but it could not influencethechange of OCB, (2) thereistheinfluence of motivation to OCB and employees' performance; the higher the motivation, it could lead to higher OCB and employees' performance, (3) there is the influence of organization culture to OCB and employees' performance; the higher the organization culture, it could lead to higher OCB and employees' performance, and (4) there is the influence of OCB to employees' performance; the higher OCB, it could lead to higher employees' performance.

Servant leadership begins when a leader assumes the position of servant in their interactions with followersthat might be held about the relationship betweenleaders and followers in an organization. Servant leaders also help employees to become better serving others, innovative, and bring such new ideas which allow the organization to grow competitively and adapt itself to the changing external environment. Thus employeescommitted to improving service quality is also very important to be developed or nurtured, and far exceeds normal expectations in their work.Unfortunately, this type of leadership is not significantly influences to OCB. Therefore, suggestion that can be presented in this study is that managers of Outstanding Cooperatives should be more empower themselves tohelp fellow workers carry out their tasks voluntarily, and implementing 
the real positive attitude, fostering sportsmanship, altruism, conscientiousness, courtesy, and civic virtue of the employees.

\section{References}

[1] Armstrong, M.\&Baron, A. 1998. Performance Management-The New Realities. London: IPD

[2] Barbuto, J., Brown, L., Wilhite, M.\&Wheeter, D. 2001.”Justify the Underlying Motives of Organizational Citizenship Behavior.” A brief study of agricultural co-op workers.

[3] Bass, B.M.1985. Leadership and Performance Beyond Expectations. New York: Free Press.

[4] Biswas, S.\&Varma, A. 2007. "Psychological Climate and Individual Performance in India: Test of a Mediated Model."Employee Relation 29(6): $664-676$.

[5] Buchanan, D.\&Huczynski, A. 1997. Organizational Behavior: An Introductory Text. 3rd Edition.London : Prentice Hall.

[6] Budiyanto\&Oetomo, H.W. 2011.'The Effect of Job Motivation, Work Environment and Leadership on Organizational Citizenship Behavior, Job Satisfaction and Public Service Quality in Magetan, East Java, Indonesia.” World Academy of Science, Engineering and Technology 7(5): 192-200.

[7] Bungin, Burhan. 2011. Quantitative Research Methodology, Communication, Economic, Public Policy, and Other Social Sciences. 2 nd ed. Jakarta: Kencana Prenada Media Group.

[8] Campbell, D., Stonehouse, G.,\&Houston, B. 1999. Business Strategy. Butterworth Heinemann.

[9] Central Bureau of Statistic, East Java in Number. 2012.

[10] Covey, S. 1995. Principle-Centered Leadership.Simon and Schuster.

[11] Cummings, L.L.\&Schwab, D.P. 1973. Performance in Organisations: Determinants and Appraisal. Glenview: Scott, Foresman and Company.

[12] Deluga, R.J.1994. "Supervisor Trust Building, Leader-member Exchange and Organizational Citizenship Behavior.Journal of Occupational and Organizational Psychology, 67(4), 315-332.

[13] Di Tomasso, Gordon, 1992. "Producing Corporate Performance FromOrganizationa Culture” Journal of Management Studies 29 (6): 783-798.

[14] East Java Governor Act. No. 188/389/KPTS/013/2012. Regional Government East Java.

[15] Ferdinand, A. 2006. Management Research Methods: Guidance for Writing Minithesis, Thesis, and Dissertation of Management Science. Economic Faculty. Semarang: Diponegoro University.

[16] Fey, C.F.\&Denison, D.N. 2000. "Organizational Culture and Effectiveness: The Case of Foreign Firms in Russia and Sweden," Working Paper Services in Business Administration 4: 123-165

[17] Greenleaf, R. 1970. Servant as Leader.Center for Applied Study. Indianapolis: The Robert K Greenleaf Center.

[18] Hall, J. 1996. The Competence Connection: A Blueprint for Excellence. Woodlands: Woodstead Press.

[19] Hayward, B.A. 2005. Relationship Between Employee Performance,Leadership and Emotional Intelligence in a South African ParastatalOrganisation. A Thesis.Grahamstown: Rhodes University.

[20] Hofstede, G. 1980. Culture`s Consequences. London: Sage.

[21] Jahangir, N., Akbar, M.M., Haq, M. 2004. "Organizational Citizenship Behavior: It's Nature and Antecedents." BRAC University Journal I (2): 75-85.

[22] Jogulu, U. D. 2010. "Culturally Linked Leadership Style."Leadership and Organizational Development Journal 31(8): 705-719.

[23] Jo, S.J.\&Joo, B.K. 2011.'The Influences of Learning Organization Culture Organizational Commitment, and Organizational Citizenship Behaviors.” Knowledge Sharing 1: 2-20.

[24] Kim, Sangmook. 2006. "Public Service Motivation and Organizational Citizenship Behavior in Korea." International Journal of Manpower 27(8): 772-740.

[25] Koesmono, H.T.2005. "Job Satisfaction and Employees' Performance on Subsector of Middle Scale Wood Processing Industry East Java."Research Center Journal. Surabaya: Christian Petra University 6(2): 163-175.

[26] Lawler, E.E., III 1994. Motivation in Work Organizations. San Fransisco: Jossey-Bass Inc. Publishers.

[27] Mehta, R.,Dubinsky, A.J.\&Anderson, R.E. 2003. "Leadership Style, Motivation and Performance in International Marketing Channels: An Empirical Investigation of the USA, Finland and Poland."European Journal of Marketing.37(1/2): 50-85.

[28] Mathis, Robert L.\&Jackson, John H. 2002. Human Resource Management, 9th ed., Ohio: South-Western Publishing.

[29] Moynihan ML, Timothy MG, Patrick MW. 2002. "High Performance HR Practice and Customer Satisfaction: Employee Process Mechanism". CAHRS Working Paper, (02-09), Cornell University: 1-27.

[30] Nystrom, P.C.1993. "Organizational Cultures, Strategies, and Commitments in Health Care Organizations." Health Care Manage Review 18: 43-49.

[31] Organ. D. W. 1988. Organizational Citizenship Behavior: The Good Soldier Syndrome. Lexington: Lexington, MA.

[32] Penner, L.A, Midili, A.R\&Kegelmeyer, J. 1997. Beyond Job Attitudes: a Personality and Social Psychology Perspective on the Causes of Organizational Citizenship Behavior. HumanPerformance 10(2): 111-131.

[33] Robbins, Stephen P. 1998. Organization Behavior : Concept, Controversy, Application, the 7th Edition. Jakarta: Prehallindo.

[34] Sabir, M.S, Sohail, A\&Khan, M.A. 2011. "Impact Leadership Style on Organization Commitment: In A Mediating Role of Employee Values."Journal of Economics and Behavioral Studies 3(2): 145-152.

[35] Sari, A.R.\&Ja'far, M. S. 2010. "The Impact of Target Setting on Managerial Motivation and Performance.”Accountancy National Seminar XII.Purwokerto: General Soedirman University.

[36] Smith, C.A., Organ, D.W.\&Near, J.P. 1983. "Organizational Citizenship Behavior: Its Nature and Antecedents.”Journal of Applied Psychology. 68 (6): 653-663.

[37] Solimun. 2008. Modeling of Structural Equal: PLS and SEM Approach, Smart PLS and AMOS Software Application. Malang: Statistics FMIPA Lab. Brawijaya University.

[38] Somech, A.\&Drach-Zahavy, A. (2004). Exploring organizational citizenship behavior from an organizational perspective: The relationship between organizational learning and organizational citizenship behavior.Journal of Occupational and Organizational Psychology, 77, 281-298.

[39] Spears, L.C. 1995. Tracing The Growing Impact of Servant Leadership. NY: John Wiley\&Sons.

[40] Storseth, F. 2004. "Maintaining Work Motivation During Organizational Change.” Int. J. Hum. Res. Dev. Manage., 4(3): 267-287.

[41] Subramaniam, P.A.B. 2011.’The Influence of Leadership Style on Organization Commitment. "Human Resource Management College of Business.Universiti Utara Malaysia.

[42] Tang, T.L.P.\&Ibrahim, A.H.S. 1998. "Antecedents of Organizational Citizenship Behavior: Public Personnel in the United States and in the Middle East." Public Personnel Management 27: 529-548. 
[43] Wayne, S., Shore, L.\&Liden, R. 1997. "Perceived Organizational Support and Leader-Member Exchange: A social Exchange Perspective."Academy of Management Journal 40(1): 82-111.

[44] Werner, J.M. 2000. "Implications of OCB and Contextual Performance for Human Resource Management."Human Resource Management Review 10(1): 3-24.

[45] Williams, L. J.\& Anderson, S. E. 1999. Job Satisfaction and Organizational Commitment as Predictors of Organizational Citizenship and In-role Behaviors.Journal of Management, 17(3), 601-617.

[46] Wong, Paul T.P.\&Page, D. 2003. "Servant leadership: An Opponent-Process Model and the Revised Servant Leadership Profile."Servant Leadership Roundtable 3: 1-13.

[47] Zabihi, M.\&Hashemzehi, R. 2012. "The Relationship Between Leadership Styles and Organizational Citizenship Behavior." African Journal of Business Management 6(9): 3310-3319. 